TAPROBANICA, ISSN 1800-427X. April, 2012. Vol. 04, No. 01: pp. 42-47.

(C) Taprobanica Private Limited, Jl. Kuricang 18 Gd.9 No.47, Ciputat 15412, Tangerang, Indonesia.

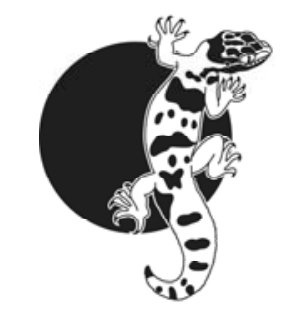

\title{
EXPANDED DESCRIPTION OF Enhydris dussumierii (DUMÉRIL, BIBRON \& DUMÉRIL, 1854) (REPTILIA: COLUBRIDAE: HOMALOPSINAE)
}

\author{
S. R. Chandramouli ${ }^{1}$, Baiju ${ }^{2}$, J. J. Sebastien ${ }^{3}$ and S. R. Ganesh ${ }^{1,4}$
}

\footnotetext{
${ }^{1}$ Deptment of Zoology, A. V. C. College, Mannampandal, Mayiladuthurai 609305, TamilNadu, India

${ }^{2}$ Poojapura Open Snake Park, Agada Thandra Serpentarium, Thiruvananthapuram 695004, Kerala, India

${ }^{3}$ Thiruvananthapuram Zoological Park and Museum, Palayam, Thiruvananthapuram 695033, Kerala, India

${ }^{4}$ Chennai Snake Park,Rajbhavan post, Chennai 600022,Tamil Nadu, India

Email: snakeranglerr@gmail.com
}

\begin{abstract}
Description of a poorly-known endemic Indian homalopsid water snake Enhydris dussumierii is expanded based on character state data obtained anew from newly examined live and preserved specimens in captive facilities. Knowledge on the natural history of this uncommon, endemic species is supplemented by our observations. Further field surveys in southwestern Indian coastal plains are recommended for fully documenting the geographic range of this species.
\end{abstract}

Key words: Morphology, scalation, body form, colouration, distribution, India

\section{Introduction}

The Oriental, homalopsid, water snake genus Enhydris Sonnini \& Latrielle, 1802 currently comprises 25 valid species that are characterized by large head shields, smooth scales, nasals in contact behind rostral, a single or double internasal posterior to the nasals, 19-33 midbody scalerows, 105-172 ventrals, 23-92 subcaudals. They are distributed from the Indus River Valley of Pakistan in the northwest to the Queensland coast of Australia in the southeast. Only two species, $E$. enhydris (Schneider, 1799) and E. plumbea (Boie, 1827) are widespread, while the remaining 23 species are restricted to drainage systems and coastlines of specific bioregions and ecoregions and are consequently poorly-known in terms of systematics, ecology and life-history traits (Murphy, 2007).

Enhydris dussumierii (Duméril, Bibron \& Duméril, 1854) is one of the poorly-known members of this genus, endemic to a small geographical region, i.e., the southwestern coastal plains of India, in Kerala state. This species was originally described as Eurostus dussumierii based on two syntypes MNHN 3751 and 3752 collected by Jean-Jacques Dussumier from "Côte de Malabar, Inde" and "Bengale” respectively (Fig. 1). Currently one subjective junior synonym Hypsirhina malabarica 
Werner 1924 (synonymy fide, Smith, 1943) is known and since its name bearing type is believed to be lost (Smith, 1943). Hypsirhina malabarica was synonymized under Enhydris dussumierii by Smith (1943) without comparing the type of $H$. malabarica. Therfore Gyi (1970) and Murphy (2007) considered the status of $H$. malabarica is uncertain; hence its systematic status remains as yet unresolved. Gyi (1970) and Murphy (2007) provided modern-day redescriptions of the two syntypes of Enhydris dussumierii. Moreover Murphy (2007) provided additional localities from near its type locality and also published in-life colour photographs by Ingrid Simpson. Three more individuals were sighted in Vellayani Lake ca. 200 airline $\mathrm{km}$ south of its known distribution and their morphology, prey, total length and tail length were documented (Kumar \& Captain, 2011). This apart, nothing is known about the taxonomy of this species.
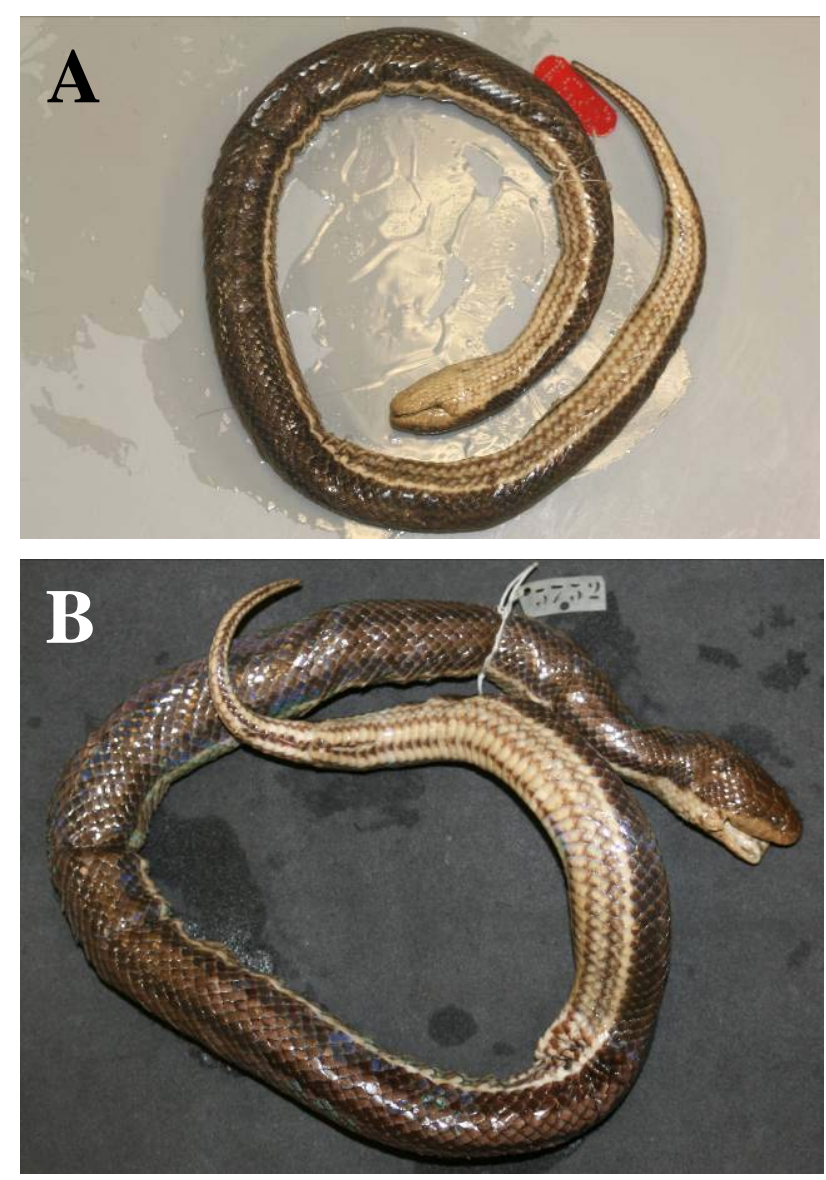

Figure 1: Syntypes of Enhydris dussumierii; (A) MNHN 3751, (B) MNHN 3752.

Despite Duméril et al.'s description in 1854 and the subsequent recognition by Jan (1868), some renowned treatises on Indian reptiles (Günther, 1864; Theobald, 1876; Boulenger, 1890) did not mention this species in their works. This pitiful plight parallels just a few hand-picked Indian snakes like Coluber vittacaudatus Blyth, 1854 and Tropidolaemus huttoni (Smith, 1949) (see Whitaker \& Captain, 2004). Even after Smith's (1943) inclusion into the Indian snake fauna, more recent works on Indian snakes (Daniel, 2002; Das, 2002; Whitaker \& Captain, 2004), did not throw light on this species owing to lack of adequate data. The natural history of this species is only available in Parameshwaran (1954, 1963). Gyi (1970) and Murphy (2007) unfortunately miswrote the status and numbers of the type specimens of $E$. dussumierii (see Kumar \& Captain, 2011). Kumar \& Captain (2011) wrote "The species was first described by Duméril et al. (1854) as E. dussumieri [sic]" and "Scientific nomenclature is that used by Whitaker and Captain (2004) - Enhydris dussumierii, instead of Enhydris dussumieri as listed by Murphy (2007), Gyi (1970) and Smith (1943)”. Unfortunately, Kumar \& Captain (2011) overlooked the fact that Duméril et al. (1854) originally described this species as "Euroste De Dussumier Eurostus Dussumierii Nobis" and therefore dussumierii is the original correct spelling. Moreover, Kumar \& Captain's mention of "E. dussumieri [sic]" leaves little clue as to whether their "E." refers to generic name Eurostus or Enhydris. Sadly, Parameshwaran (1954, 1963) incorrectly attributed the taxon authorship of $E$. dussumierii.

\section{Materials and Methods}

We examined 10 individuals (nine live and one preserved, i.e. nearly twice the number of documented specimens), maintained in captive facilities (zoological parks) in Thiruvananathapuram, Kerala. Scale counts, measurements and colour pattern data were recorded from nine live and one preserved specimens. Anterior dorsal scale rows were counted at one head length posterior to head, midbody scalerows were counted at the middle of snout-vent length and posterior scalerows were counted at one head length anterior to vent. Scales after the preventrals up to the scale before the anal scale were counted as ventrals (Dowling, 1951). The terminal scute was excluded from the number of subcaudals. Scales between rostral and the final scale bordering jaw angle were counted as supralabials, those touching eye, given within parenthesis. Scales between mental and scale below last supralabial were counted as infralabials, those touching genials given within parenthesis. Scales surrounded by supralabials, postoculars and 
parietals were counted as temporals. Symmetrical head scalation character values were given in the order of left / right. Measurements except snoutvent and total lengths, which were measured with a standard measuring tape, were taken using vernier calipers and expressed to the nearest millimeter. Dentition and primary sexual characters were not examined as we were working with live captive animals on exhibit. Snakes were photographed using Canon EOS 400D and Powershot A620 model digital cameras. Geographic coordinates and altitude (in meters above sea level) were recorded using Google Earth Software ver. 5.0 beta.

\section{Observations and discussion}

\section{Enhydris dussumierii (Duméril, Bibron and Duméril, 1854)}

Body form (mean values in mm): Overall build stocky and robust; snout moderately rounded; eyes and nostrils placed dorsally; head slightly longer than broad (head length: 27, head width: 25.5); neck slightly evident (head width: 25.5, neck width: 22); nostril closer to snout-tip (2) and then to lip (3.5) than to eye (6.5); eye diameter: 2.5; distance between snout-tip and posterior endpoint of parietals nearly half of that between snout-tip and jaw-angle; snout to vent length: 617; total length: 700; tail small (relative tail length: $11 \%$ of total length) (Fig. 2).

Scalation: Rostral visible from above, smaller than nasal, triangular, broader than long; nasal pierced by nostril, squarish, rounded or bean-shaped, with a nasal cleft; internasals 2, smaller than nasals, posterior to nasals, triangular, touching each other, this side the shortest, trapezoidal, with a median division; together these scales as broad as rostral, but shorter than combined width of both the nasals or both the prefrontals; prefrontals 2; frontal longer than broad, pentagonal, posteriorly tapering triangularly towards a point where it gets higher than posterior edge of supraocular; supraocular much shorter than frontal, trapezoidal, its anterior margin bordering a small scale, thus separated from upper margin of loreal; loreal 1, horizontally rectangular to trapezoid, subequal to orbit but as big as basal postocular and anterior temporal, in contact with $2^{\text {nd }}$ supralabial; parietals nearly twice as long as broad, lung-shaped, contacting at midline by an indented medial suture that starts from edge of frontal, the suture's length equal to maximum width of parietal, parietal posteriorly divided into Yshape; occipital small, rhomboid; preocular 1, pentagonal, higher than broad, as high as orbit, higher than loreal, narrowly elongate, fully touching supraocular, just touching prefrontal but not internasal, from which it is separated by the small scale as mentioned earlier, in contact with $3^{\text {rd }}$ supralabial; postoculars two, basal one larger, trapezoid and in full contact with $5^{\text {th }}$ supralabial; anterior temporal 1 , six sided, as large as loreal and basal postocular; posterior temporals 2-3, lower one larger, almost twice as large as the upper one; basal one mildly contacts $6^{\text {th }}$ supralabial while the upper one contacts parietal; supralabials $8-9 \quad\left(4^{\text {th }}-5^{\text {th }}\right.$ touching eye), higher than broad, squarish or vertically rectangular; sometimes with small triangular scales between $4^{\text {th }}, 5^{\text {th }}$ and $6^{\text {th }}$ scales; $6^{\text {th }}$ one largest, six sided, bulged, contributing to the head height / depth, $7^{\text {th }}$ and $8^{\text {th }}$ ones horizontally divided into upper and lower; infralabials 12-13 $\left(5^{\text {th }}-7^{\text {th }}\right.$ touching genials), progressively smaller, $1^{\text {st }}$ one narrow and elongate, extending towards anterior genials; posterior genials smaller, $1 / 4^{\text {th }}$ the size of anterior; linguals 8-9, contributing to posterior commencement of preventrals; preventrals 3 , broken-up anteriorly, but yet broader than surrounding scales; suture dividing genials deep, with a furrow and extensible interstitial skin; gular scales, homogenous, as large as linguals, almost similarly oriented (i.e., posterodorsally); ventrals 142-151, angulate laterally, narrow; coastals rhomboid, homogenous throughout, two outermost scalerows slightly larger; dorsals smooth, not imbricate, glossy; anterior scalerows 29 , reducing to $27[3+4 \rightarrow 3 / 4+5 \rightarrow 4]$ at $6^{\text {th }}-12^{\text {th }}(x=9)$ ventral; midbody scalerow 27 , reducing to $25(\mathrm{n}=3)$ or 23 $(\mathrm{n}=7)[2+3 \rightarrow 2 / 4+5 \rightarrow 4]$ at $109^{\text {th }}-131^{\text {st }}(\mathrm{x}=120)$ ventral; anal divided; subcaudals 27-40 pairs, divided.

Colouration in life: Dorsum dull to reddish or olivaceous brown from $5^{\text {th }} / 6^{\text {th }}$ to $19^{\text {th }} / 21^{\text {st }}$ scalerows; three black stripes, one in the middle flanked by the other two extending from parietals to tail-tip; middorsal stripe feeble, discontinuous, occupying $13^{\text {th }}$ scalerow; lateral stripes occupying $5^{\text {th }}-7^{\text {th }}$ scalerows on either side; ventral colour variable, from creamy white to deep ochre orange, but always with three black stripes extending from preventrals to terminal subcaudal scale; midstripe formed by a small, one scale-large, black patch present in the middle of each ventral, that gives a striped appearance, as it is present in all consecutive ventrals; head and forebody scales with a pale yellow border, visible anteriorly, obscure to invisible posteriorly; last three rows of coastals bear a distinct black border, the posteriormost of last scalerow, intensely 
bordered, thus demarcating the ventrals on the sides; iris fawn brown; pupil dark, small, rounded.
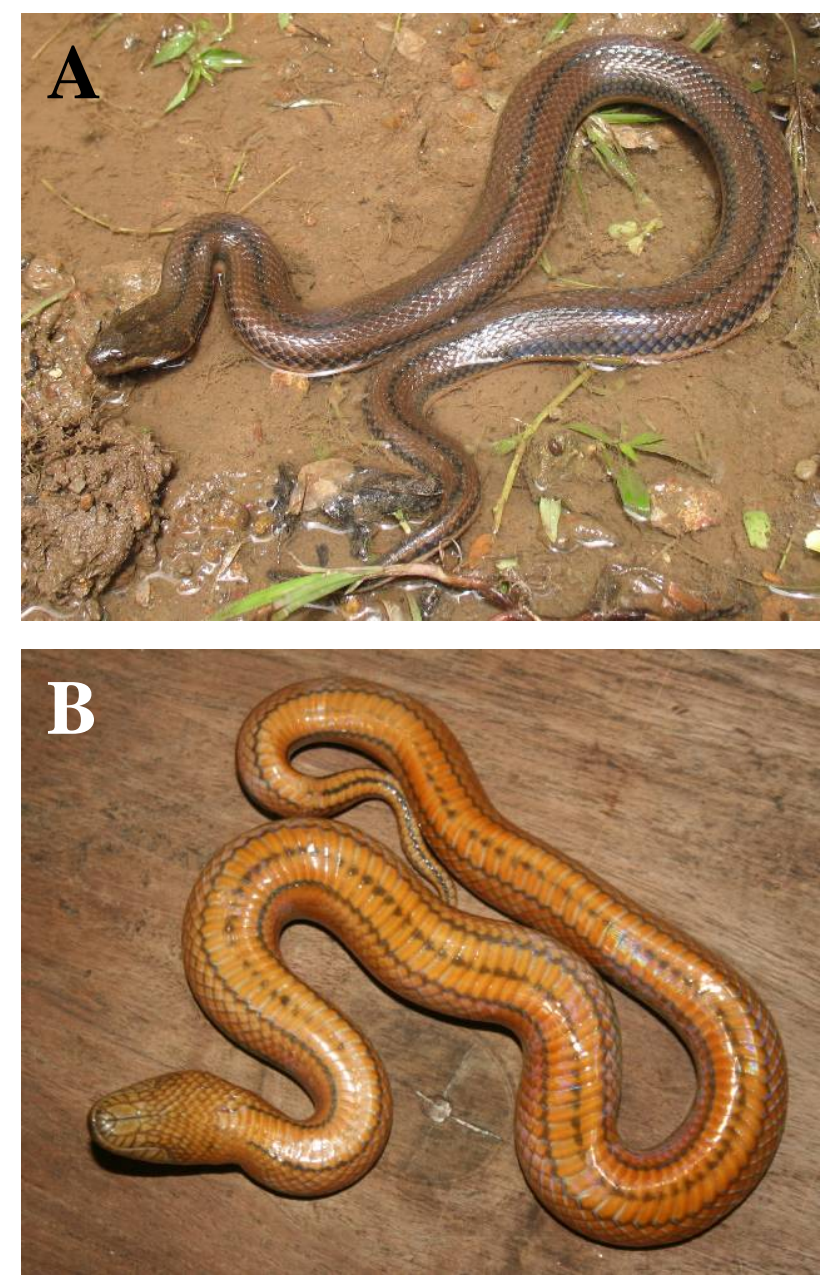

Figure 2: Enhydris dussumierii in life (A) dorsal, (B) ventral views

Colouration in preservative: Dorsum olivaceous to grayish brown; the stripes visible as in the live specimens, but of duller colour; ventrals pale, with a similar striped pattern; stripes dark grayish brown; iris dull brown; pupil less discernable.

Natural history: During field visits in search for snakes, we observed this species to be docile and little defensive when dealt with. Fishermen who encountered this species informed us that some individuals bite if handled, causing mild swelling at the bite-site coupled with localized and intermittent throbbing pain. As is typical of this genus, during daytime, this species often takes refuge in marshy substratum of water-bodies, more so in stagnant ponds and nearby aquatic vegetation like wetland rushes (Ipomea) and water hyacinths (Eichhornia). Individuals have been observed to be out and active during late evenings and night in inundated rice paddies (Oryza) and banana (Musa) groves. It often drops down and submerges from water-land interfaces at the sign of human-approach. Like most water snakes, it is more abundant during rainy season. Our experiences with the husbandry of captive snakes reveal that they feed on fishes such as Anabas sp., Catla sp., Channa sp., Labeo sp., Puntius sp. etc.

Morphology of our individuals is slightly expanding the morphological characterization (Table 1), (Duméril et al., 1854; Smith, 1943; Gyi, 1970; Murphy, 2007; Kumar \& Captain, 2011). Our observations on the natural history of this species are consistent with that of existing literature accounts (Parameshwaran, 1954; Kumar \& Captain, 2011). Exhaustive accounts on its reproduction have been published by Parameshwaran (1954; 1963). Future field studies might result in a better understand its ecology and life history.

Recent records further south of its type locality indicate the potential possibility of its occurrence in other parts of coastal Kerala and probably Kanyakumari District of Tamil Nadu. However, it is one of the many Enhydris species with a very narrow range of distribution.

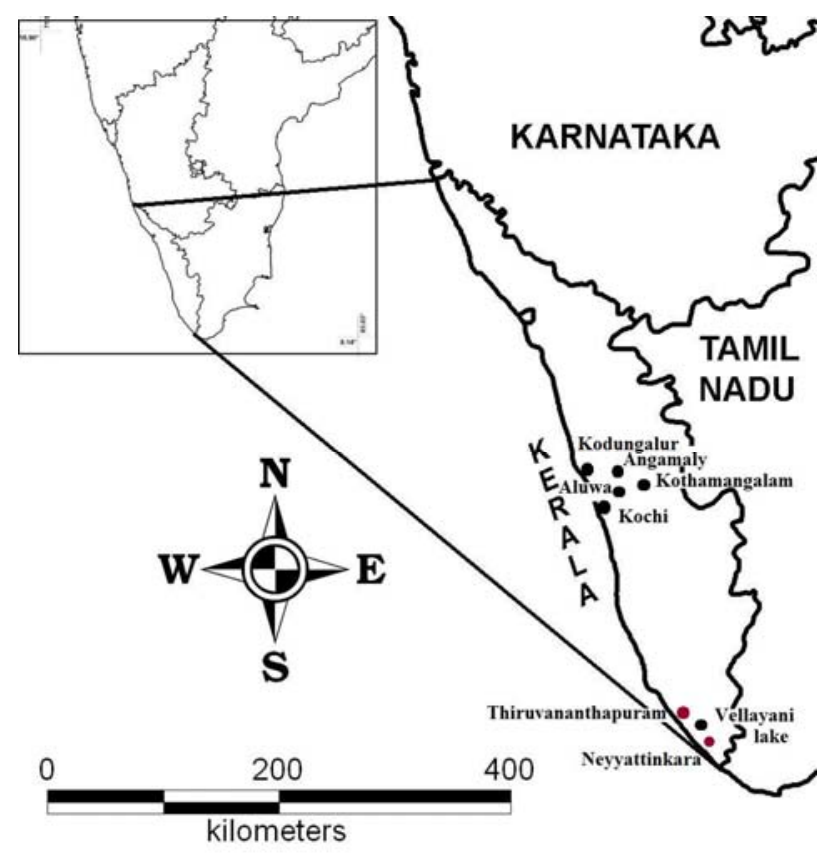

Figure 3: Distribution of Enhydris dussumierii 
Table 1: Comparison of selected characters of our ten individuals vs. literature data

\begin{tabular}{|l|c|c|c|c|c|}
\hline \multicolumn{1}{|c|}{ Characters } & $\begin{array}{c}\text { Smith } \\
(\mathbf{1 9 4 3})\end{array}$ & $\begin{array}{c}\text { Sharma } \\
\mathbf{( 2 0 0 3 )}\end{array}$ & $\begin{array}{c}\text { Murphy } \\
\mathbf{( 2 0 0 7 )}\end{array}$ & $\begin{array}{c}\text { Kumar \& } \\
\text { Captain (2011) }\end{array}$ & This work \\
\hline Ventrals & $144-150$ & $143-150$ & $144-148$ & $147-150$ & $142-151$ \\
\hline Subcaudals & $34-39$ & $28-39$ & $31-38$ & $36-38$ & $27-40$ \\
\hline Supralabials (touching eye) & $8(4)$ & $8(4)$ & $8(4)$ & $8(4)$ & $8-9(4-5)$ \\
\hline $\begin{array}{l}\text { Infralabials (touching anterior } \\
\text { genials) }\end{array}$ & $?(5)$ & $?(5)$ & $12-13(5)$ & No data & $12-13(5-7)$ \\
\hline Loreal & 1 & No data & 1 & 1 & 1 \\
\hline Temporals & $1+2$ & No data & $1+3+3$ & $1+2$ & $1+2,1+3$ \\
\hline Max. snout-vent length (mm) & 595 & No data & 670 & 565 & 795 \\
\hline Max. total length (mm) & 670 & 670 & 744 & 655 & 920 \\
\hline
\end{tabular}

Table 2: Distribution data summarizing recorded localities

\begin{tabular}{|c|c|c|c|c|c|}
\hline Locality name & District & N Lat. & E Long. & $\begin{array}{c}\text { Elevation } \\
\text { (m a.s.l.) }\end{array}$ & Literature / source \\
\hline Cote de Malabar & $?$ & ca. 8-11 & ca. 76-77 & $?$ & Duméril et al. (1854) \\
\hline Bengale (in error) & $?$ & $?$ & $?$ & $?$ & Duméril et al. (1854) \\
\hline North Travancore & $\begin{array}{c}\text { Ernakulam, Thrissur, } \\
\text { Malappuram }\end{array}$ & ca. 9-10 & ca. 76 & $<20$ & Parameshwaran (1954) \\
\hline Cochin (= Kochi) & Ernakulam & 09.56 & 76.15 & 04 & Murphy (2007) \\
\hline Kodungallur & Thrissur & 10.13 & 76.11 & 11 & Murphy (2007) \\
\hline Kothamangalam & Ernakulam & 10.03 & 76.37 & 22 & Murphy (2007) \\
\hline Angamaly & Ernakulam & 10.12 & 76.22 & 19 & Murphy (2007) \\
\hline Aluva (=Alawye) & Ernakulam & 10.06 & 76.21 & 11 & Murphy (2007) \\
\hline Chalakudy & Thrissur & 10.18 & 76.20 & 18 & Murphy (2007) \\
\hline Olavipe & Ernakulam & 09.29 & 76.19 & 09 & Murphy (2007) \\
\hline Vellayani & Thiruvananthapuram & 08.25 & 76.59 & 08 & Kumar \& Captain (2011) \\
\hline Aakkulam & Thiruvananthapuram & 08.31 & 76.54 & 17 & This work \\
\hline Sreekaryam & Thiruvananthapuram & 08.32 & 76.55 & 46 & This work \\
\hline Olathanni, Neyyttinkara & Thiruvananthapuram & 08.22 & 77.04 & 19 & This work \\
\hline
\end{tabular}

\section{Acknowledgements}

We thank our respective institutions for support and logistics; Abiram Shankar for logistic facilities at Thiruvananthapuram; Edward Garfred for French translation; Shreyas Krishnan and O. S. G. Pauwels for their comments; P. David, C. J. Murphy and H. $\mathrm{K}$. Voris for details and photographs of the syntypes.

\section{Literature cited}

Boulenger, G. A., 1890. Fauna of British India, including Ceylon and Burma; Reptilia and Batrachia. Taylor and Francis, London: 560.

Daniel, J. C., 2002. The Book of Indian Reptiles and Amphibians. Oxford University Press, Mumbai, India: 238.

Das, I., 2002. A Photographic Guide to Snakes and other Reptiles of India. New Holland publications, London, UK: 144.
Dowling, H. G., 1951. A proposed standard system of counting ventrals in snakes. British Journal of Herpetology, 1 (5): 97-99.

Duméril, A, G. Bibron and E. Duméril, 1854. Erpétologie générale, ou Histoire naturelle compléte des reptiles. Paris, 7 (2): 953-955.

Günther, A. C. L. G., 1864. The Reptiles of British India. The Ray Society, London: 550.

Gyi, K. K., 1970. A Revision of Colubrid Snakes of the Subfamily Homalopsinae, Museum of Natural History, University of Kansas, Lawrence, No. 20: 223.

Jan, G., 1868. Iconographie Genéralé des Ophidians. Milan:

Kumar, A. B., A. Captain., 2011. Recent records of the endemic Kerala mud snake, Enhydris dussumierii (Duméril, Bibron \& Duméril, 1854) from India. Current Science 100: 928-931. 
Murphy, J. C., 2007, Homalopsid snakes-Evolution in the Mud. Krieger Publishing Co., U.S.A: 260.

Parameswaran, K. N., 1954. On the viviparous habit of the fresh-water snake, Enhydris dussumieri (Smith). Current Science, 1: 27-28.

Parameswaran, K. N. 1963. The foetal membranes and placentation of Enhydris dussumieri (Smith). Proceedings of Indian Academy of Sciences, SectionB, 56: 302-327.

Sharma, R. C., 2003. Handbook - Indian Snakes. Director- Zoological Survey of India, Kolkata: 292.

Smith, M. A., 1943. Fauna of British India, including Ceylon and Burma. Vol- III Serpentes, Taylor and Francis publications, London: 583.

Theobald, W. 1876. Descriptive Catalogue of the Reptiles of British India. Thacker Spink and Co., Calcutta, India: 238.

Whitaker, R., A. Captain, 2004. Snakes of India - The Field Guide. Draco Books, Chengalpet, South India: 481. 